International Research Journal of Management, IT \& Social Sciences
Available online at https://sloap.org/journals/index.php/irjmis/
Vol. 6 No. 5, September 2019, pages: 25 39
ISSN: 2395-7492
https://doi.org/10.21744/irjmis.v6n5.694

\title{
Absorption of Capital Expenditure Budget on Regional Apparatus Organization in East Nusa Tenggara Province
}

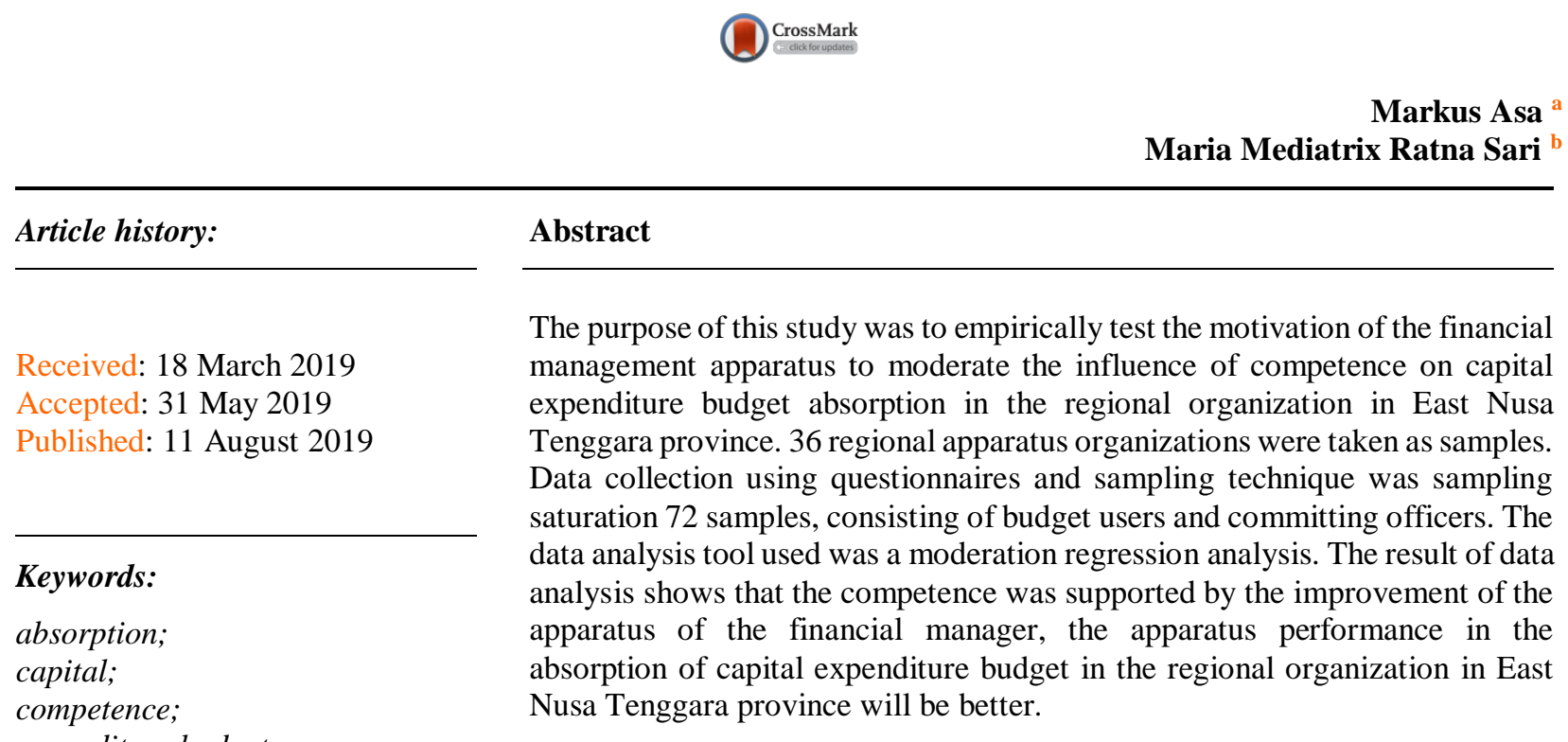

expenditure budget;

motivation;

2395-7492@ Copyright 2019. The Author. This is an open-access article under the CC BY-SA license (https://creativecommons.org/licenses/by-sa/4.0/) All rights reserved.

\section{Author correspondence:}

Markus Asa,

Udayana University, Denpasar, Indonesia.

Email address: markusasa07@gmail.com

\section{Introduction}

Public financial management is conducted by delegating authority to the regions. It is called regional autonomy and fiscal decentralization. Regional autonomy is basically an instrument used in the implementation of state development. Society welfare achievement as the country is the main goal. Regional autonomy and fiscal decentralization are implemented as drivers of development at the local government level. It is hoped the community aspirations and needs in the regions can become the development priority.

It was issued Law No. 32/2004) concerning regional government and Law No. 33/2004 concerning the financial balance between the central government and regional government was issued on regional autonomy and fiscal decentralization. The laws regulate the principles of the authority transfer to regional governments as well as funding for the authority implementation.

The authority of the financial management of each autonomous region has positive and negative impacts. The positive impacts of regional autonomy include (1) The potential of each region can be developed more leverage. (2)

\footnotetext{
a Udayana University, Denpasar, Indonesia

${ }^{\mathrm{b}}$ Udayana University, Denpasar, Indonesia
} 
The full authority of the regional government in issuing policies on the context of optimally managing natural resources, impacting on increasing regional income, and bureaucracy costs becoming more efficient. The negative impacts include (1) Lack of coordination between regions because each region feels, it has authority or autonomy, (2) Poor regions slowly develop due to lack of regional budget revenue (PAD) (www.ilmuekonomi.net, 2015).

The financial authorities granting for each the provincial, regency/city autonomous regional governments are expected to be able to maximize the financial budget plans. It has been set out on regional expenditure budget (APBD). The development process in the regions is carried out faster. However, in reality, the budget absorption on each autonomous regions did not reach the target as expected.

Based on an evaluation from the Director-General of Regional Finance of the Ministry of Home Affairs of the Republic of Indonesia, the budget absorption pattern from provinces, regencies/cities in Indonesia is only pursued at the year-end. Wherein, the pattern will not be efficient (Astadi et al., 2015). Based on APBD budget absorption data provinces in Indonesia, semester I/2016 is not only one province reached the target of 50 percent, but also there were four provinces. There did not reach 20\%, namely North Maluku 19.47\%, DKI Jakarta 19,23\%, North Kalimantan $16.39 \%$, and Jambi $13.21 \%$.

The evaluation results show on semester I/2016, the absorption rate of the regional budget in NTT Province 2015 only reached $36.55 \%$. It means it was still far from 50\% supposed to target. This certainly has a negative impact on the development acceleration process in NTT Province. Details on the absorption in NTT Province's capital expenditure budget can be seen in Table 1 .

Table 1

Absorption on capital expenditure budget, NTT province, 2013-2016

\begin{tabular}{|l|l|l|l|l|l|}
\hline No & Year & Target & Realization & Difference & Percentage \\
\hline 1 & 2013 & $779,678,357.77$ & $755,747,653.37$ & $23,930,704.40$ & 96.9 \\
\hline 2 & 2014 & $1,066,512,187.13$ & $955,008,639.25$ & $111,503,547.88$ & 89.5 \\
\hline 3 & 2015 & $1,283,703,880.73$ & $1,283,703,880.73$ & - & 100.0 \\
\hline 4 & 2016 & $1,464,700,526.99$ & $1,309,678,360.40$ & $155,022,166.59$ & 89.4 \\
\hline
\end{tabular}

Source: BPS data processed, 2016

Table 1 shows the absorption percentage fluctuates of NTT Province's capital expenditure budget in 2013-2016. The absorption of the capital expenditure budget in 2013 was $96.9 \%$. There was a decrease in 2014 to $89.5 \%$ or a decrease of $7.4 \%$ compared to 2013 and in 2015 increased again to $100 \%$. It in 2016 declined again to $89.4 \%$ or decreased by $10.6 \%$ compared to 2015 .

Budget absorption does not reach the target set. It is influenced by several factors including the competence of human resources. The higher competency of financial management apparatus is on each Local Government Organizations $(O P D)$. It is better absorption of the budget (Manafe, 2015). The other factor causes the minimum budget absorption is budget planning. Poor budget planning becomes a major obstacle to budget absorption. It means budget planning has a large impact on budget absorption. Therefore, better budget planning is better to budget absorption and the procurement of goods and services. If the procurement process of service goods is good, the budget absorption will be better. The procurement process for service goods is effective. The efficient will facilitate the process of budget absorption. It has an impact on the mechanism of budget payment/disbursement (Gagola, 2016).

Empirical research on budget absorption has been conducted. Juliani (2013), shows that management commitment, knowledge of regulations, and the bureaucratic environment has a positive effect on budget absorption. It is related to the procurement of goods/services. Manafe (2015), suggested that the factors on influence capital expenditure consist of geographical conditions, natural conditions, and weak planning, administrative factors, human resources and the factors of the tender/procurement of goods and services. It is to take a long time. Madyaningsih (2015), the procurement activities of goods/services on the Regional Office of the Ministry of Law and Human Rights Daerah Istimewa Yogyakarta have been going well. However, the implementation has not been optimal or not in accordance with the objectives to be achieved. Suherlan (2014), explains that the effectiveness of budget absorption is categorized as sufficient or normal. Purtanto (2015), shows that monitoring and evaluation and competence have no effect on the absorption of goods and services expenditure budget.

Robbins \& Judge (2008), stated that competence is the ability or capacity of someone to do various tasks in a job determined by two factors, namely intellectual ability and physical ability. The more someone is competent in their 
field of work, the quality or performance of an organization or institution will be better. An employee's competency can be improved by attending various education and training related to their work area.

Syarifudin (2014), stated that human resources (HR) competencies have an effect on the delays on spending absorption to ministries/institutions in Jakarta area. Furthermore, Malahayati et al., (2015), stated that HR capacity influences the budget absorption in Banda Aceh City SKPD. Likewise, Wardhana (2015), stated that competence influences performance. Ridani (2015), also stated HR competence influences budget absorption regional expenditure. Safwan et al., (2014), suggested that competence and motivation together or partially influencing the performance of regional financial management in Pidie Jaya Regency. Contrasting to Purtanto (2015), stated that HR competencies have a negative effect on budget absorption. It means that the more competent a financial manager is not able to increase budget absorption. Similar results are also found by Syarifudin (2014), stated that HR competencies have no effect on the quality of local government financial reports.

Contingency factors can affect the relationship between competence and budget absorption. Murray (1990), suggested that to reconcile conflicting results, a contingency approach is needed to identify other variables. The act is as moderators or mediators in the research model. Based on this study, the researchers chose motivation as a moderating variable on the grounds of using motivational variables. Due to one's competence, however, without being based on high motivation, it can result in decreased performance productivity.

Arifin (2016), suggested that motivation as a motivating factor in acting, moving, and directing in a certain way. Therefore, the goals of an organization can be achieved. According to Sachau (2007), stated that motivation is based on the theory of two factors, namely hygiene and motivators. The people in carrying out their work are influenced by two factors, namely (1) maintenance factors are related to the human's nature who want to obtain physical welfare. The needs will continue, due to a need will return to zero after being fulfilled. (2) motivation factors are related to one's psychological needs. It is a perfect feeling of doing work, respect for individuals directly related to work.

Sukmasari (2011), shows that motivation has a significant effect on the performance of financial management employees. It is in accordance with Angella \& Puspasari (2014). It is suggested that motivation has a significant effect on employee performance.

It is a strong reason based on the previous description for researchers to test the motivation of financial management apparatus to moderate the influence of the competence of financial management apparatus on capital expenditure budget absorption. There are differences incompetence enough to provide a reference for researchers to conduct research on the performance of the apparatus in the budget absorption in OPD NTT Province. It is related to the competencies and motivations of the financial management apparatus.

There is a difference between the previous research. It is related to the research location in OPDs NTT Province. The reason for choosing it due to being related the budget management. Another problem raised in the low absorption of the capital expenditure budget in NTT Province. It has an impact on the slow development process in the province.

Based on the above issues and phenomena described, the purpose of this study namely (1) to obtain empirical data on the influence of the competence of financial management apparatuses on the absorption of capital expenditure budgets in OPD NTT Province. (2) to obtain empirical data on the motivation of the financial management apparatus to moderate the influence of the competence of the financial management apparatus on the absorption of the capital expenditure budget in OPD NTT Province.

\section{Theoretical Review}

Competence is the ability or capacity to do various tasks in a job. Wherein, this ability is determined by two factors, namely intellectual abilities and physical abilities (Robbins \& Judge, 2007). Competence according to Palan (2007), is as a basic characteristic possessed by an individual who is causally related in meeting the criteria needed in occupying a position. Competence consists of five characteristics types, namely motives (consistent will as well as being on action cause), innate factors (consistent character and response), self-concept (self-image), knowledge (information in a particular field), and skills (ability to carry out tasks).

Fogg (1987), divides competencies into two categories namely threshold and differentiating according to the criteria used to predict job performance. Threshold competencies are the main characteristics. It is usually in the form of basic knowledge or skills, unlike the ability to read while differentiating competency is to make one different from others.

Organizational performance clearly includes organization performance members. The work success on each member of the organization becomes important for the achievement. According to Law No. 13/2003 concerning manpower, work competency is the work ability for every individual. It includes aspects of knowledge, skills, and

Asa, M., \& Sari, M. M. R. (2019). Absorption of capital expenditure budget on regional apparatus organization in East Nusa Tenggara province. International Research Journal of Management, IT and Social Sciences, 6(5), 25-39. 
work attitudes. It was in accordance with established standards. The head of the State Civil Service Agency (BKN) No. $7 / 2013$ concerning guidelines for the formulation of managerial competency standards and work capabilities. The cover aspects included knowledge, skills, and attitudes in accordance with the duties and/or position functions.

Budget absorption is one of the budget cycle stages that starts with budget planning, budgeting, and approval by the Indonesian legislative assembly (DPR), budget absorption, budget oversight, and budget absorption accountability. This absorption stage of the budget begins when the State Budget (APBN) Law is passed by DPR. Budget absorption according to Kuncoro (2013), is preparing stage and determining the budget up to budget accountability stage. The budget implementation is relating to the management of state finances conducted by officials of the State Ministry/institutions as budget users/budget authority and according to statutory provisions, laws applied.

Noviwijaya et al., (2013) stated that the absorption of work unit budgets is the proportion of work unit budgets that have been disbursed or realized in one fiscal year. The Minister of Finance Regulation No. 249/PMK.02/2011 in Gagola et al., (2016), stated that budget absorption is one indicator of performance evaluation on aspects of implementation. Budget absorption is also an element of financial accountability in the Government Agency Performance Accountability Report (LAKIP). BPKP explained in 2011 that the failure of the budget absorption target did indeed result in the loss of expenditure benefits because not all funds allocated could be utilized by the government. It defines that there were funds that were unemployed resulting in low budget absorption.

The Law No. 101/PMK.02/2011 concerning the budgets classification, defines capital expenditures as expenditures made in the context of capital formation. It is to add fixed assets/inventory that provides benefits for more than one accounting period, including expenses for maintenance costs. It is to maintain or increase the useful life and, increase the capacity and assets quality.

Capital expenditures consist of several types of capital expenditures, namely (1) Land capital expenditures are expenditures/costs used for procurement/purchase/release, settlement, transferring land name and lease, emptying, withdrawing, leveling, land maturation, certificate making and expenditure others related to the acquisition of land rights and until the established land is in ready-to-use condition. (2) Equipment capital expenditure and equipment are expenses/costs used for procurement/addition/replacement and capacity improvement of equipment and machinery and office inventory that provides benefits for more than two twelve months and until the established equipment and machinery are in ready-to-use condition. (3) Building capital expenditures are expenditures/costs used for procurement/addition/replacement and include expenditures for planning, supervision, and buildings management that add capacity to the building and the building referred in ready-to-use conditions. (4) Capital expenditure on roads, irrigation, and networks are expenditures/costs used to procure/add replacement/increase construction/manufacture and maintenance and include expenditures for planning, supervision, and management of irrigation roads and networks. It is to add capacity to roads irrigation and network referred to in ready-to-use conditions. (5) Other physical capital expenditures are expenditures/costs used to procure/add replacement/increase construction/manufacture as well as other physical treatments. It cannot be categorized into criteria for capital, land, and equipment capital expenditure, buildings as well as irrigation roads and networks. This expenditure is included capital expenditures for lease contracts, purchases of art items, archaeological goods, and goods for museums, livestock and plants, books and scientific journals.

The previous study is regarded as the effect of competence conducted by Wardhana (2015), stated competence affected performance. Ramdan (2008), also stated that HR competence affected the absorption of regional budgets. Likewise, Efendi (2015), suggested that competence and motivation both jointly and partially affect the performance of regional financial management in the Government of Pidie Jaya Regency. Based on the previous description, it can be formulated hypotheses.

H1: Competency of financial management apparatus has a positive impact on the capital absorption budget.

The motivation role is very important in achieving organizational goals. Therefore, it must be understood the human motivation to work in an organization or company. Robbins \& Judge (2008), suggested that motivation as a stage on producing an interaction, goals, and individual perseverance in an effort to achieve a goal. As a basis on motivation, the three elements are focused motivation process. Intensity relates to how hard an employee tries. High intensity will not bring the desired results. The effort unless is directed at the achievement of organizational goals. Efforts are directed consistently towards achieving organizational goals. It will produce perseverance. Perseverance is a measure of how long employees keep their business. Motivation as a condition or energy that moves employees to be directed achieving the objectives of the company's organization (Mangkunegara, 2005; Aggarwal, 2017; Nneka et al., 2016).

Motivation factor consists of two indicators namely attitude and situation. Attitudes can be interpreted as a person's mental status and attitudes can be expressed in various ways with different words and intensity levels. The situation 
can be interpreted as an atmosphere. It can determine the employee attitude. Employee behavior is much influenced by the situation definition, if the employee defines something as real then the consequences become real.

Gomes (2003), suggested that indicators measure work motivation consists of two parts, namely individual factors and organizational factors. Classified as individual factors are needs, goals, attitudes, and abilities. The organizational factors consist of payment of salary, job security, employee relations, supervision, praise, and the work itself. Whereas, Hasibuan (2009), stated groups motivation into two types, namely (1) Direct motivation, namely motivation (material and non-material) given directly to each individual to meet their needs and satisfaction. (2) The indirect motivation provided as facilities form that supports the passion for work/fluency of tasks. Therefore, the employees feel at home and eager to do their jobs.

Siagian (2000), classified motivation in several indicators namely (1) human needs are not only material, but human needs are also psychological, mental, intellectual, and even spiritual. (2) motivational and maintenance are things intrinsic achievement and comes from a person. The hygiene factor is an extrinsic factor. It means the sourced from outside oneself. (3) Justice that humans are driven to eliminate the gap between the effort made for the organization benefit and the rewards received. (4) The expectation is a result to be achieved by a person and the estimate in question about his actions will lead to the desired results.

It can be concluded based on the above understanding that motivation as an impulse from within a person (employee) produces an attitude to move all abilities for themselves to achieve organizational goals in an effort to meet some individual needs. This motivational variable basically supports the motivation theory as the grand theory. It has been described previously.

Efendi (2019), suggested that competence and motivation both jointly and partially influence the performance of regional financial management in the Government of Pidie Jaya Regency. Sukmasari (2011), shows that motivation has a significant effect on financial management employee performance. This is in accordance with Puspasari (2014), stated that motivation significantly influences employee performance. Nurhayati (2017), shows that motivation can strengthen the influence of leadership on the performance of the Village Treasurer in Tabanan Regency. Based on the theory and some above research, the research hypothesis can be formulated.

H2: Motivation of financial managers apparatus strengthens the positive effect of competency of financial managers apparatus on the capital absorption budget.

The research model is structured to explain the influence between variables. It aims to provide a scientific explanation based on theoretical foundations and empirical studies (Sugiyono, 2014). Based on the problem formulation and the mindset, the independent variable is the competency of financial management apparatus (X), while the dependent variable is the absorption of capital expenditure budget (Y), and the motivation of financial management apparatus as a moderating variable $(\mathrm{Z})$. Based on the number of variables described above, a concept is developed that explains the relationship between variables as shown in Figure 1.

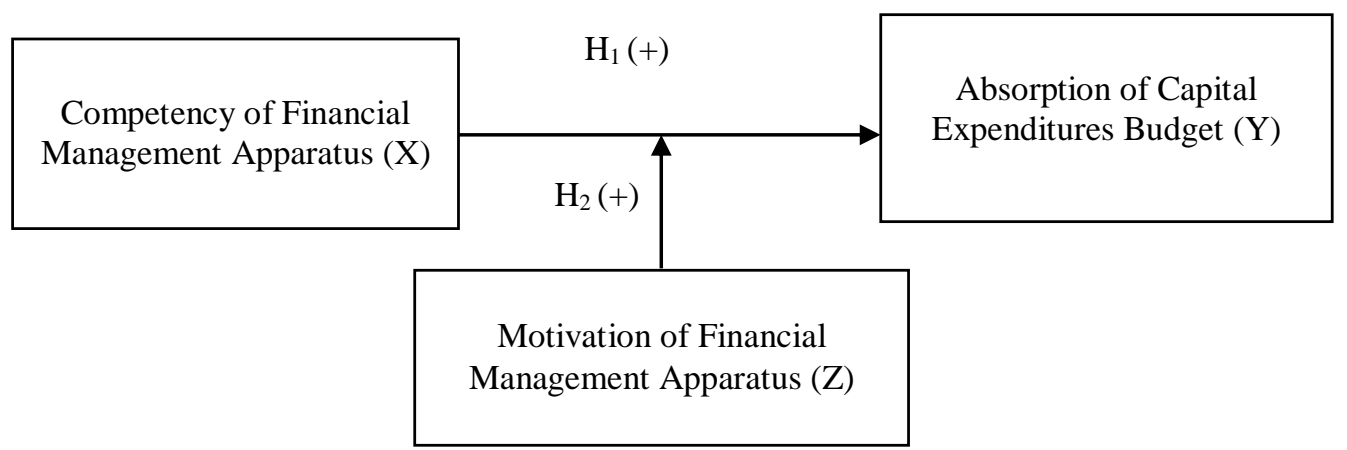

Figure 1. Research model

Figure 1 explained that the competency of the financial management apparatus is hypothesized to have a positive effect on the absorption of the capital expenditure budget. According to Malahayati et al., (2015), stated that human resource competency is one of the important factors in increasing absorption budget. Therefore, the motivation of the financial management apparatus is hypothesized to strengthen the influence of the competence of the financial processing apparatus on the absorption of the capital expenditure budget. This is based on prior research conducted

Asa, M., \& Sari, M. M. R. (2019). Absorption of capital expenditure budget on regional apparatus organization in East Nusa Tenggara province. International Research Journal of Management, IT and Social Sciences, 6(5), 25-39. https://doi.org/10.21744/irjmis.v6n5.694 
by Efendi (2019), suggested that competency and motivation both jointly and partially affect the performance of regional financial management in the Government of Pidie Jaya Regency.

\section{Materials and Methods}

The purpose of this study is to analyze the effect of the competence of financial management apparatus on capital expenditure budget absorption. It is moderated by the motivation of financial management apparatus. There are three variables namely the competence of financial management apparatus, capital expenditure budget absorption, and motivation of financial management apparatus.

This research was conducted for two months. Those were October and November 2017 at OPD NTT Province. The selection of OPD NTT Province as the research object because these are related to the absorption of capital expenditure budget. The scope of this research is limited to the financial management apparatus, in this case, the budget user (PA) and authority commitment officer (PPK).

The current research uses a qualitative research approach which is more descriptive in nature. The data collected is in the form of words. It does not emphasize numbers. According to the nature of the data used in this study, classified as quantitative data, in the form of numbers or representations of reality symbolically numerically (with numbers) (Sugiyono, 2007). Quantitative data includes NTT Province's capital expenditure budget absorption data as well as the respondent's answers questions about competency, motivation, and budget absorption. These are then summarized on a Likert scale. Meanwhile, according to the source, classified as primary data are the statements of respondents listed in the questionnaire circulated.

The population is a generalization area consisting of objects and subjects. It has been certain qualities or characteristics determined by researchers to be studied and drawn conclusions (Sugiyono, 2012). The population in this study are financial management officials Government of OPD NTT Provincial, namely PA and PPK, 26 offices, 8 agencies, and 2 offices (Regional Personnel Agency) of NTT Province's BPK. Thus, the total population was 36 OPD x 2 samples (budget users, and commitment making officials) and the total respondent is 72 respondents.

The sample is part of the number and characteristics possessed by the population (Sugiyono, 2012). The sampling technique in this study is the census, namely, all populations consisting of financial management officials, included PA and PPK, OPD in NTT Province as well as a survey method with a questionnaire as a method of collecting data. Based on the problem formulation, the variables are as follows.

1) Independent variable, namely variable that influence/cause changes/the emergence of dependent variables (Sugiyono, 2014). In this research, the independent variable is the competency of financial management apparatus (X)

2) Moderating variable is a variable that can strengthen and weaken the relationship between the independent variable and the dependent variable (Sugiyono, 2012). The moderating variable in this study is the motivation of financial management apparatus (Z)

3) Dependent variable, namely variable that is affected or become a result due to the presence of independent variables (Sugiyono, 2014).

Capital expenditure absorption is the dependent variable (Y) in this study. According to Indriantoro \& Supomo (1999), stated that the operational definition of a variable is constructed determination or the definition given to a variable that can be measured. This study used three variables consisting of one dependent variable (Y), namely the absorption of capital expenditure budget, one independent variable (X), namely competency of financial management apparatus, and one moderating variable $(\mathrm{Z})$ motivation of financial management apparatus as moderating. These variables can be explained as follows.

\section{1) Competency of financial management apparatus $(X)$}

According to Spencer (1993), competence is a basic characteristic possessed by an individual who is causally related in meeting the criteria needed in occupying a position. Competence consists of five characteristics types, namely motives (consistent will as well as being the action cause), innate factors (consistent character and response), self-concept (self-image), knowledge (information in a particular field) and skills (ability to carry out tasks). Competence is used to measure perceptions of financial management officials on the mechanism of capital expenditure absorption. There are three indicators used to measure the competency 
variables, namely skills, knowledge, and attitude. The instrument used was a questionnaire model developed by Hertanto (2011), which consisted of 11 questions.

2) Motivation of financial management apparatus $(Z)$

According to Sardiman (2011), mentioned motives can be interpreted as an effort to encourage someone to do something. Motives can be stated as a driving force from within-subject to carry out certain activities in order to achieve a goal. Even, the motive can be stated as an internal condition (preparedness). Starting from the word motive, then motivation can be interpreted as a driving force that has become active. Motives become active at certain times, especially, at the time the need to reach a goal is felt or urgent.

Work motivation is a shared desire to achieve goals, loyalty to the organization and leadership, high and good work discipline, able to face difficulties in conducting work, and high interest and love for working. According to Gomes (2003) as for the indicators to measure work motivation which consists of two parts, namely individual factors and organizational factors. Classified as individual factors are the needs, goals, attitudes, and abilities. Whereas, classified as organizational factors included payment of salaries, job security, employee relations, supervision, praise, and the job itself. Motivational questionnaire questions Abraham Maslow model developed by Hertanto (2011), which consists of 11 questions.

3) Absorption of capital expenditures budget $(Y)$

According to (President Regulation No. 73 Article 5/2011) stated that the Minister/Head of the institution that controls the budget has the authorization authority. It is responsible for the use of the budget within the ministry/institution s/he leads. Thus, it can be concluded that any budget approved by the legislature. The head of the institution controls the budget is obliged to spend the budget in accordance with the plan on APBN/APBD.

The budget absorption variable is measured by three indicators namely the percentage of budget absorption, revision, and suitability of the budget line in the Budget Implementation Entry List (DIPA) which are elaborated in 11 questions sourced from the Decision of the Director-General of the Treasury (Purnomo, 2010), concerning technical guidelines for monitoring and evaluation of absorption the budget.

In order to empirically test the influence of the competence of the financial management apparatus on capital expenditure budget absorption and the motivation of the financial management apparatus to moderate the influence of the competency of the financial management apparatus on capital expenditure budget absorption in OPD NTT Province, the data collected were analyzed using the inferential statistics.

The regression model will be used as an unbiased estimation tool, if it meets the BLUE (Best Linear Unlimited Estimator) requirements, namely the data analyzed must be normally distributed. The assumption testing is also intended to find out the results of the regression estimation conducted completely free from the presence of heteroscedasticity symptoms. If there is heteroscedasticity, the variance is not constant. Therefore, it can cause a standard error bias. Testing the assumption of normality and heteroscedasticity using SPSS software version 22 for windows.

\section{1) Normality test}

Ghozali (2011), stated that the normality test aims to test whether the regression model of the dependent variable and the independent variables both have normal distribution or not. Residual normality test is conducted using the Kolmogorov-Smirnov test with a significance level of 5\%. The normality test results are seen on the One-Sample Kolmogorov-Smirnov Test. The normality assumption test results on the One-Sample Kolmogorov-Smirnov Test, also the normality assumption data can be seen from the normal plot graph. The decision-making criteria are $\mathrm{Sig} \geq 0.05$ then the data are stated to be normally distributed. If the Sig value $<0.05$ then the data is stated to have an abnormal distribution. Whereas, in a normal plot graph, data or variable points spread around the diagonal line and the distribution follows the direction of the diagonal line.

2) Heteroscedasticity Test

According to Ghozali (2013), the heteroskedasticity test aims to test whether in the regression model. There is an unequal variance from the residuals of one observation to another (error value). A good regression model is homoscedasticity, not heteroscedasticity. The study used the Glejser test and scatterplot graphs to ensure whether heteroskedasticity assumptions are met. It is compared with $\alpha 5 \%$ and on the scatterplot graph, the distribution of data points will be seen. Criteria fulfilled heteroskedasticity assumption is a significant value > $\alpha 5 \%$ and the data points distribution on the scatterplot graph are both above and below the zero vertical or horizontal lines.

Asa, M., \& Sari, M. M. R. (2019). Absorption of capital expenditure budget on regional apparatus organization in East Nusa Tenggara province. International Research Journal of Management, IT and Social Sciences, 6(5), 25-39. https://doi.org/10.21744/irjmis.v6n5.694 
Descriptive statistics are used to analyze data by providing data description. That is seen from the average value (mean), standard deviation, maximum value, and minimum value. Descriptive statistics are used to analyze data, therefore, the sample used does not provide generalized conclusions.

This study used moderation regression analysis (MRA) with SPSS (Statistical Program and Service Solution). Regression analysis is a linear relationship between two or more independent variables with the dependent variable. Regression analysis is used to look at the dependence of the dependent variable with one or more independent variables. It aims at estimating the average value of the dependent variable based on the value of the known independent variable (Ghozali, 2014). Hypothesis testing is conducted by using a moderation regression analysis for $H I$ that tests the direct effect of the competency variable of financial management apparatus on capital expenditure budget absorption and $H 2$ that tests the interaction between the variable motivation of financial management apparatus and financial manager apparatus competency on capital expenditure budget absorption.

MRA is an interaction test which is a special application of simple linear regression. Wherein the regression equation contains interaction elements (multiplication of two or more independent variables) (Liana, 2009). Interaction test is used to test the interaction of competency variables of financial management apparatus on capital expenditure budget absorption with the motivation of financial management apparatus as a moderating variable. The following equation models are used to answer $H 1$ and $H 2$. The following equation models are used to answer $H 1$ and $H 2$, namely:

$$
\begin{aligned}
& Y=\alpha+\beta_{1} X_{1}+\beta_{2} Z_{1}+\varepsilon \ldots \ldots \ldots \ldots \ldots \text { (1) } \\
& Y=\alpha+\beta_{1} X_{1}+\beta_{2} Z_{1}+\beta_{3} X_{1} \cdot Z_{1}+\varepsilon \ldots \ldots .(2) \\
& \begin{array}{ll}
\text { Description: } & \\
Y & =\text { capital expenditure budget absorption } \\
\alpha & =\text { constant } \\
\beta_{1}, \beta_{2}, \beta_{3} & =\text { regression coefficients } \\
X_{1} & =\text { competency of financial management apparatus } \\
Z_{1} & =\text { motivation of the financial management apparatus } \\
\text { e } & =\text { error }
\end{array}
\end{aligned}
$$

\section{1) Determination coefficient test $\left(R^{2}\right)$}

This test is denoted by $R^{2}$. It defines a test is conducted to determine the extent of the model's ability to explain the dependent variable. The determination coefficient is between zero and one. If the $R^{2}$ value is getting closer to zero. It means that the ability of the independent variable in explaining the variation of the dependent variable is very limited, and vice versa if the $R^{2}$ value is close to one. It means that the independent variables provide almost all the information needed to predict the dependent variable.

2) Model feasibility test (F Test)

$F$ Test is used to determine the effect of the independent variables together on the dependent variable (Ghozali, 2013). F Test is conducted to test whether the regression model used is fit. The basis for decision making is to pay attention to the output of regression results using SPSS with a significance of $0.05(\alpha=0.05)$. If the $\mathrm{F}$ test results are significant or $\mathrm{P}-\mathrm{Value} \leq 0.05$. It can be concluded that the independent variables are significant influence the dependent variable and the regression model used is considered feasible.

Hypothesis testing uses MRA method in which there are two hypotheses to be tested, to find out which moderating variables are able to moderate the dependent variable. The relationship between the independent variable of competence with the dependent variable absorption of capital expenditure budget is characterized by identifying the regression coefficient. If the regression coefficient is positive. It is concluded that the relationship between competence with the absorption of the budget is unidirectional. However, if the opposite is negative then the relationship between the competency variables with the budget absorption is the opposite.

Interaction test results show that the coefficient of the interaction variable is not significant while the moderating variable is significant. It means that the moderating variable is a pure moderator variable. However, on the contrary, if the interaction results testing show interaction variables, and moderation variables are equally significant. Therefore, moderating variables can be used as independent variables as well as moderation or commonly called quasi moderators (Ghozali, 2013; Pattiasina et al., 2019; Nuryani et al., 2018). 


\section{Results and Discussions}

The distribution and return of the questionnaire were conducted in October and November 2017 in OPD NTT Province, namely to the head of office/head of the agency as PA and PPK. The number of questionnaires distributed was 72 questionnaires and all of them were successfully returned by the researchers.

One condition that must be fulfilled by an instrument is validity. Validity is related to the extent to which the measuring instrument is able to measure what should be measured. Testing the instruments validity using the KMO MSA model. Factor analysis shows that the construction specifications developed theoretically whether they are in accordance with the underlying construct concepts after field trials. Thus, factor analysis essentially is a filter analysis technique to analyze the relationship between instrument items.

Factor analysis used the correlation principle. It means that if a valid indicator measures a latent variable. It must correlate significantly and strongly with other indicators among its latent variables. Factor analysis examines the correlation between fellow indicators (items). The correlation significance is in the Sig value in Bartlet's Test of Sphericity and the correlation strength is on KMO MSA (kaiser-meyer-olkin measure of sampling adequacy) value. It varies from 0 to 1. An item is stated to be valid if (a) Sig value in Bartlet's $<5 \%$ (b) there is a strong correlation between an item and other items seen from KMO MSA value of all items $>50 \%$, anti-image Correlation value > 50\%, and component/factor loading factor > 50\%, (Ghozali, 2014; Gorda et al., 2018). The research instrument consisting of question items from the variable competency of financial management apparatus (X), the motivation of financial management apparatus $(\mathrm{Z})$, absorption of capital expenditure budget $(\mathrm{Y})$ is declared valid. This is due to the Sig value in Bartlet's for all items is $0,000<5 \%$, the KMO MSA value for the variable competency of financial management apparatus is 0.913 or $91 \%$, the variable motivation of financial management apparatus is 0.901 or $90 \%$ and the variable absorption of capital expenditure budget is 0.913 or $91>50 \%$ and anti-image correlation values for all items $>50 \%$, and matrix component/loading factor values for all items $>50 \%$.

Reliability is the measurement consistency or the consistency of the resulting score. The Cronbach's alpha value of the financial management apparatus competency $(\mathrm{X})$ variable is 0.978 , the financial management apparatus motivation $(\mathrm{Z})$ variable is 0.969 and the capital expenditure budget $(\mathrm{Y})$ variable is 0.968 . Each variable has a Cronbach's alpha value greater than alpha 0.70 . thus, it is stated that all variables are reliable. Information on each variable characteristics used in this study in detail can be seen in Table 2 .

Table 2

Descriptive statistics results

\begin{tabular}{|c|c|c|c|c|c|c|}
\hline No & Variable & $\mathrm{N}$ & Min & Max & Average & $\begin{array}{l}\text { Standard } \\
\text { Deviation }\end{array}$ \\
\hline 1 & $\begin{array}{l}\text { Competency of financial } \\
\text { management apparatus }(\mathrm{X})\end{array}$ & 72 & 11,00 & 44,15 & 31,84 & 9,56 \\
\hline 2 & $\begin{array}{l}\text { Motivation of financial management } \\
\text { apparatus }(\mathrm{Z})\end{array}$ & 72 & 11,00 & 44,11 & 31,89 & 9,48 \\
\hline 3 & $\begin{array}{l}\text { Absorption of capital expenditures } \\
\text { budget (Y) }\end{array}$ & 72 & 11,96 & 43,09 & 31,71 & 9,51 \\
\hline
\end{tabular}

Source: Primary data processed, 2018

Tabel 2 menyajikan karakteristik dari masing-masing variabel seperti jumlah responden, nilai minimum, nilai maksimum dan nilai rata-rata. Dari Tabel 2 ini diketahui nilai rata-rata dari masing-masing variabel antara lain: kompetensi aparatur pengelola keuangan sebesar 31,84, motivasi aparatur pengelola keuangan 31,89, dan penyerapan anggaran belanja modal sebesar 31,71 .

Teknik analisis data yang digunakan dalam penelitian ini antara lain: uji asumsi klasik yang dilakukan sebagai syarat yang harus dipenuhi pada analisis regresi berganda yang berbasis ordinary least square (OLS). Selanjutnya uji kelayakan model, analisis determinasi dan uji hipotesis dimana dalam penelitian ini menggunakan analisis regresi sederhana dan analisis regresi moderasi.

Table 2 presents the characteristics of each variable such as the number of respondents, the minimum value, the maximum value, and the average value. From Table 2 it is known the average value of each variable, among others:

Asa, M., \& Sari, M. M. R. (2019). Absorption of capital expenditure budget on regional apparatus organization in East Nusa Tenggara province. International Research Journal of Management, IT and Social Sciences, 6(5), 25-39. https://doi.org/10.21744/irjmis.v6n5.694 
the competency of the financial management apparatus at 31.84, the motivation of the financial management apparatus 31.89 , and the absorption of the capital expenditure budget of 31.71 .

Data analysis techniques used in this study include a classic assumption test conducted as a condition that must be met in ordinary regression analysis based on ordinary least square (OLS). Furthermore, the feasibility test of the model, determination analysis and hypothesis testing in which this study uses simple regression analysis and moderation regression analysis.

Normality and Heteroscedasticity test are used as a classic assumption test in this study. Furthermore, each test can be explained as follows: Regression models require residuals or confounding variables to be normally distributed. To test the regression model used in this study, whether the data is normally distributed or not the Kolmogorov-Smirnov test is used. Residual values in this study are normally distributed where the Asymp value. Sig. 2 is 200 higher than the 0.05 significance.

The variables used in a study are said to be free from heteroscedasticity if all the independent variables used are not statistically significant that affect the dependent variable. The Glejser test was used in this study to determine whether there is heteroscedasticity. The independent variable used in this study is free from heteroscedasticity, where the value of sig. for the variable competency of financial management apparatus is 0.234 where this value is greater than the level of significance determined at $5 \%$ or 0.05 .

Regression analysis is used to look at the dependence of the dependent variable with one or more independent variables, with the aim of estimating the average value of the dependent variable based on the value of the known independent variable. This study uses a moderation/MRA regression model. Moderate Regression Analysis (MRA) is an interaction test conducted to determine whether a variable is a moderating variable. The results of the moderation regression analysis are presented in Table 3.

Table 3

The results of moderation regression analysis

\begin{tabular}{|c|c|c|c|c|c|}
\hline \multirow{2}{*}{ Variable } & \multicolumn{2}{|c|}{ Unstandardized Coefficients } & \multirow{2}{*}{$\begin{array}{l}\text { Standardized } \\
\text { Coefficients } \\
\text { Beta }\end{array}$} & \multirow[t]{2}{*}{$\mathrm{t}$} & \multirow{2}{*}{ Sig. } \\
\hline & B & Std. Error & & & \\
\hline Constant & 13,192 & 4,621 & & 2,855 & 0,006 \\
\hline Competency of Financial & & & & & \\
\hline Management Apparatus (X) & 0,029 & 0,179 & 0,029 & 0,163 & 0,871 \\
\hline Motivation of Financial & & & & & \\
\hline Management Apparatus (Z) & $-0,014$ & 0,191 & $-0,014$ & $-0,073$ & 0,942 \\
\hline Moderation (X.Z) & 0,017 & 0,006 & 0,840 & 2,737 & 0,008 \\
\hline $\mathrm{R}^{2}$ & 0,728 & & & & \\
\hline $\mathrm{F}$ & 60,819 & & & & 0,000 \\
\hline
\end{tabular}

Source: Primary data processed, 2018

Based on Table 3 the regression equations can be formulated.

$Y=13,192+0,029 X+0,014 Z+0,017 X * Z+e$

Based on the results of the moderation regression analysis shown in Table 3, it can then be explained, related to the model feasibility test (F statistical test) and adjusted $\mathrm{R}$ square value can be explained. $R^{2}$ determination coefficient basically to measure how far the ability models in explaining the dependent variable (Ghozali, 2013). The determination coefficient aims to determine the effect of the independent variable on the dependent variable. The data in Table 3 shows that Adjusted R Square value is 0.728 . It means that $72.8 \%$ of variations in changes in capital expenditure budget absorption can be explained by the competency variable of the financial management apparatus while the remaining $27.2 \%$ is explained by other factors not included in the model.

F-test shows whether all the independent variables included in the model have a joint effect on the dependent variable or the dependent variable. In Table 3, it shows $\mathrm{F}$ test produces $\mathrm{F}_{\text {count }}$ of 60.819 with a significance level of 0.000 , smaller than $0.05(\alpha=5 \%)$, which means the research model used is feasible and the hypothesis verification can be continued. 
There are three variables in this study, namely the independent variable, competency of financial management apparatus, the dependent variable is the absorption of capital expenditure budget and the moderating variable of the motivation of financial management apparatus. It will then be elaborated on the analysis results and interpretation of test results.

H1 stated that the competence of financial management apparatus has a positive effect on the absorption of capital expenditure budget. Based on the results of the hypothesis test shows that the competency coefficient value of financial management apparatus is 0.029 with a significance level of 0.871 , higher than the level of significance set at 0.05 . therefore, $H I$ the competence of financial management apparatus has a positive effect on the absorption of the capital expenditure budget is rejected. It means that there is no positive influence on the competence of the financial management apparatus on capital expenditure absorption. Therefore, it can be interpreted that, whether there is an increase in the competence of the financial management apparatus does not have an impact on increasing the absorption of the capital expenditure budget.

H2 stated that the motivation of the financial management apparatus strengthens the positive influence of the competence of the financial management apparatus on the absorption of the capital expenditure budget. Hypothesis test results indicate that the moderating regression coefficient value of $\mathrm{X} * \mathrm{Z}$ is positive at 0.017 with a significance level of 0.008 lower than the established significance level of 0.05 . thus, $H 2$ the motivation of financial management apparatus strengthens the positive influence of the competence of financial management apparatus on the absorption of capital expenditure budget received. It means that the motivation of the financial management apparatus is proven to be able to strengthen the influence of the competence of the financial management apparatus on the absorption of capital expenditure budget. Thus, it can be interpreted that an increase in the motivation of the financial management apparatus can improve the performance of the apparatus in the absorption of capital expenditure budget.

Hypothesis test results from the moderation regression test showed that the variable competency of financial management apparatus has a negative effect on the absorption of the capital expenditure budget. While the motivation of the financial management apparatus is proven to be able to strengthen the effect of the competence of the financial management apparatus on the absorption of the capital expenditure budget. In details, the discussion of the hypothesis test results is as follows.

H1 stated that the competence of financial management apparatus has a positive effect on the absorption of capital expenditure budget. The results showed that this hypothesis was rejected. It means that there was no positive effect on the competence of the financial management apparatus on the absorption of the capital expenditure budget in NTT Province during 2013-2016. It proves that the increasing competency of the financial management apparatus in terms of knowledge skills, and attitude through education and training does not have an impact on improving the performance of capital expenditure absorption in OPD.

The results of this study, theoretically contrary to the opinions expressed by Robbins \& Judge (2008), that the ability of individuals to complete various tasks in their work is an important factor in achieving the organization goals. The ability or capacity individually is known as competence. Likewise, the results of previous studies by Santoso (2011), stated that competence has a significant effect on audit quality and likewise Wardhana (2015) stated that competence affects the accountability of government performance. It was concluded that the competence role is very important in improving government performance in financial management. However, on the contrary, the test results of $H 1$ in this study showed that the competence of the financial management apparatus did not influence the performance of capital expenditure budget absorption in OPDs NTD Province during 2013-2016.

H1 test results in accordance with Purtanto (2015), stated that HR competencies have a negative effect on budget absorption, means that the more competent a financial manager is not able to increase the absorption of goods and services expenditure budget. Syarifudin (2014), shows that HR competencies have no effect on the quality of local government financial reports.

Syarifudin (2014), finding that the low quality of the regional government financial statements is not solely due to the low level of competence of the apparatus, but also the contribution of careless leadership/management policies. The management as a leader with various interests can make a decision that is "loose tolerance". Thus, it has an inherent risk in regional finances management.

$H 1$ test results showed no influence between the competence of the financial management apparatus on the absorption of the capital expenditure budget. It was assumed that in the public sector, the competency factor had become absolutely owned by every regional financial management apparatus as stipulated in Law No. 13/2003 concerning manpower. The competency is individual workability of each apparatus which includes aspects of knowledge, skills and work attitudes in accordance with established standards. Likewise, in the formulation of

Asa, M., \& Sari, M. M. R. (2019). Absorption of capital expenditure budget on regional apparatus organization in East Nusa Tenggara province. International Research Journal of Management, IT and Social Sciences, 6(5), 25-39. https://doi.org/10.21744/irjmis.v6n5.694 
managerial competencies issued by the Head of BKN No. 7/2013 that managerial competence and work ability cover aspects of knowledge, skills, and attitudes in accordance with the duties and/or position functions.

$H 2$ in this study is the motivation of the financial management apparatus to strengthen the positive effect of the competence of the financial management apparatus on capital expenditure budget absorption. The results showed this hypothesis was accepted. It means that the motivation of the financial management apparatus was proven to strengthen the influence of the competence of the financial management apparatus on the absorption of capital expenditure budgets in OPD NTT Province during 2013-2016. It means that no matter how much competence the financial management apparatus has without being supported by a high level of motivation for the financial management apparatus, then, an increase in capital expenditure absorption as determined will not be achieved.

This research is not in accordance with the opinion expressed by Robbins \& Judge (2008), stated that the ability for all individuals to complete various tasks in their work is an important factor in achieving the organization goals. Likewise, the results of previous studies by Harsanti et al., (2014), stated that competence has a significant effect on audit quality. Wardhana (2015), stated that competence influences government performance accountability.

Indicators used to measure the motivation of financial management apparatuses consist of individual factors and organizational factors. Classified as individual factors are needs, goals, attitudes, and abilities. Whereas, the classified as organizational factors, namely payment of salary, job security, employee relations, supervision, praise, and the job itself. These indicators are then used as a questionnaire statement. Financial management apparatus has high motivation in carrying out their duties and responsibilities. This is proven by the results of descriptive statistical tests show that all indicators outlined in the questionnaire statement, the majority of about $70 \%$ of respondents gave answers agree and strongly agree.

The results of the descriptive statistics for the variable motivation of the financial management apparatus show that not all respondent's answers are categorized as good. For example, the research statements specifically about basic needs, housing, clothing, and assurance as stipulated in the research statement where the answers do not agree to X.1 each is 12 people or $16,7 \%, \mathrm{X} .2$ is 10 people or $13.9 \%$ and X.3 is 11 people or $15.3 \%$. The disagreed percentage answers from the three items of this statement indicate that some respondents did not feel that some of their basic needs were being met as an indicator of the motivational variable. This is important for the attention of the Government of NTT Provincial. Due to the needs are intended to trigger the growth of apparatus performance motivation which has an impact on increasing the absorption of the capital expenditure budget.

This study succeeded in obtaining empirical evidence that the competency variable of the financial management apparatus did not have a positive effect on the absorption of the capital expenditure budget. However, the variable motivation of the financial management apparatus is able to strengthen the competence influence of the financial management apparatus on the absorption of the expenditure budget on capital.

Based on these results, several practical implications can be given as input, especially, to the Government of NTT Province in improving the performance of capital expenditure budget absorption included: basic, housing, clothing and assurance. It is to improve the recruitment and placement system in accordance with the qualifications of each officer who is placed as a financial manager in each OPD.

\section{Conclusion}

The conclusions formulated from the tested results are included (1) The competence of the financial management apparatus in OPD NTT Province does not affect the absorption of the capital expenditure budget. It shows that increasing the competency of the financial management apparatus does not have an impact on increasing the performance of the apparatus in absorbing the capital expenditure budget. (2) The motivation of the financial management apparatus strengthens the competence influence of the financial management apparatus on the absorption of the capital expenditure budget. It shows that after the motivation variable has been included, an increase in the competence influence of the financial management apparatus on the absorption of the capital expenditure budget.

The results showed that the competency of the financial management apparatus had a negative effect on the performance of the apparatus in the absorption of the capital expenditure budget in OPDs NTT Province. It means that increasing the competency of the financial management apparatus does not have an impact on improving the performance of the apparatus in absorbing the capital expenditure budget. 
Suggestions

The inclusion of the motivational variable was conducted, an increase in influence occurs. The competency of financial management apparatus in capital expenditure budget absorption. It is hoped that in the future the Government of NTT Provincial will pay more attention and continue to increase the motivation of the financial management apparatus by paying attention to basic needs, housing, clothing, and old-age insurance. Another important matter for the attention is the improvement of the recruitment and placement system in accordance with the qualifications of each officer who is placed as a financial manager in each OPD.

Many limitations in the current study, both from the number of variables and data collection methods. Therefore, suggestions that can be given to further researchers are (1) Adding variables such as leadership style, top management commitment, planning quality, partner/contractor conditions, procurement of goods and services, as well as geographical and natural conditions, and monitoring systems. (2) In collecting data, it is necessary to use interview methods to reduce the weaknesses related to internal validity.

Conflict of interest statement and funding sources

The authors declared that they have no competing interest.

Statement of authorship

The authors have a responsibility for the conception and design of the study. The authors have approved the final article.

\section{Acknowledgments}

The authors would like to thank the Editor of IRJMIS for their valuable time, support, and advice in completing the current study.

Asa, M., \& Sari, M. M. R. (2019). Absorption of capital expenditure budget on regional apparatus organization in East Nusa Tenggara province. International Research Journal of Management, IT and Social Sciences, 6(5), 25-39. https://doi.org/10.21744/irjmis.v6n5.694 


\section{References}

Aggarwal, R. (2017). Different avenues of capital market (secondary market) available for investing in market of yamuna nagar. International Research Journal of Management, IT and Social Sciences, 4(3), 34-50.

Arifin, Z. (2016). Penerapan Metode Analytical Hierarchy Process (AHP) Untuk Menentukan Sisa Hasil Usaha Pada Koperasi Pegawai Negeri. Informatika Mulawarman: Jurnal Ilmiah Ilmu Komputer, 5(2), 1-12.

Astadi, N. G., Sutarja, I. N., \& Nadiasa, M. (2015). Analisis Sistem Pengadaan Proyek Konstruksi Terhadap Penyerapan Anggaran Pemerintah Kabupaten Badung. Jurnal Spektran.

Efendi, N. (2015). Pengembangan sumber daya manusia berbasis kompetensi di kantor pemerintah kota bandar lampung. MIMBAR, Jurnal Sosial dan Pembangunan, 31(1), 1-10.

ELIMANAFE, A. D. (2015). Analisis faktor-faktor yang memengaruhi penyerapan anggaran belanja modal di kabupaten rote ndao (Doctoral dissertation, Universitas Gadjah Mada).

Faustino, C. G. (2003). Manajemen Sumber Daya Manusia. Yogyakarta: Penerbit Andi.

Fogg, G. E., \& Thake, B. (1987). Algal cultures and phytoplankton ecology. Univ of Wisconsin Press.

Gagola, L., Sondakh, J., \& Warongan, J. (2017). Analisis Faktor-Faktor yang Mempengaruhi Penyerapan Anggaran Pendapatan dan Belanja Daerah (APBD) Pemerintah Kabupaten Kepulauan Talaud. JURNAL RISET AKUNTANSI DAN AUDITING" GOODWILL", 8(1).

Ghozali, I. (2006). Aplikasi analisis multivariate dengan program SPSS. Badan Penerbit Universitas Diponegoro.

Ghozali, I. (2011). Aplikasi Analisis Multivariat Dengan Program IMB SPSS. Semarang: Badan Penerbit Universitas Diponegoro.

Gorda, A. O. S., Romayanti, K. N., \& Anggreswari, N. P. Y. (2018). Social capital, spiritual capital, human capital, and financial capital in the management of child welfare institutions. International Journal of Social Sciences and Humanities, 2(3), 12-20. https://doi.org/10.29332/ijssh.v2n3.183

Harsanti, P., Mulyani, S., \& Fahmi, N. (2014). Analisis Determinan Ketepatan Waktu Corporate Internet Reporting pada Perusahaan Yang Terdaftar di Bursa Efek Indonesia. Jurnal Dinamika Ekonomi \& Bisnis, 11(1).

Hasibuan, S. P. (2009). Malayu. 2009. Manajemen Sumber Daya Manusia.

Hertanto, E. (2011). Pengaruh Stressor, Kepuasan Kerja Dan Lingkungan Kerja Terhadap Kinerja Karyawan Pt. Putera Dharma Industri Pulogadung Jakarta Timur (Doctoral dissertation, UPN" VETERAN" YOGYAKARTA).

Indriantoro, N., \& Supomo, B. (1999). Metodologi penelitian bisnis untuk akuntansi dan manajemen. Bpfe.

JULIANI, D. (2014). Pengaruh Komitmen Manajemen, Pengetahuan Peraturan, Lingkungan Birokrasi, dan Pengawasan Keluaran terhadap Penyerapan Anggaran Pemerintah Daerah: Proses Pengadaan Barang/Jasa (Doctoral dissertation, Universitas Gadjah Mada).

Kuncoro, E. D. (2013). Analisis Penyerapan Anggaran Pasca Penerapan Aplikasi Sipp Pada Satker Pelaksanaan Jalan Nasional Wil. I Dinas Pu Prov. Kaltim. eJournal Administrasi Bisnis, 1(4), 364-373.

Liana, L. (2009). Penggunaan MRA dengan SPSS untuk menguji pengaruh variabel moderating terhadap hubungan antara variabel independen dan variabel dependen. Dinamik, 14(2).

Malahayati, C., \& Islahuddin, H. B. (2015). Pengaruh kapasitas sumber daya manusia, perencanaan anggaran dan pelaksanaan anggaran terhadap serapan anggaran satuan kerja perangkat daerah (skpd) pada pemerintah kota banda aceh. Jurnal Administrasi Akuntansi: Program Pascasarjana Unsyiah, 4(1).

Mangkunegara, A. P., \& Prabu, A. (2005). Perilaku dan budaya organisasi. Bandung: Refika Aditama.

Murdani, M., \& Suherlan, A. (2014). Analisis Efektivitas dan Efisiensi Penyerapan Anggaran Pendidikan dan Kesehatan dalam APBD Kabupaten Aceh Besar pada Periode 2008-2012. Signifikan: Jurnal Ilmu Ekonomi, 3(2).

Murray, D. (1990). The performance effects of participative budgeting: An integration of intervening and moderating variables. Behavioral Research in accounting, 2(2), 104-123.

Ningsih, M. S. M., Atmadja, A. T., SE, A., Herawati, N. T., \& AK, S. (2016). Analisis Penetapan Harga Pokok Produksi Banten Rsigana Sebagai Sarana Upacara Agama Hindu (Studi Kasus Pada Usaha Banten Milik I Nengah Sedana di Desa Datah, Kecamatan Abang, Kabupaten Karangasem). JIMAT (Jurnal Ilmiah Mahasiswa Akuntansi) Undiksha, 3(1).

Nneka, M., Anthony, K. A., \& Ann, O. (2016). Effective management of intellectual capital and organizational performance on selected manufacturing firms in Nigeria. International Research Journal of Management, IT and Social Sciences, 3(11), 22-32.

Noviwijaya, A., \& Rohman, A. (2013). Pengaruh Keragaman Gender dan Usia Pejabat Perbendaharaan Terhadap Penyerapan Anggaran Satuan Kerja (Studi Empiris pada Satuan Kerja Lingkup Pembayaran KPPN Semarang I) (Doctoral dissertation, Fakultas Ekonomika dan Bisnis). 
Nurhayati, E. (2017). Pengaruh Pengalaman, Independensi, dan Time Budget Pressure Terhadap Kualitas Audit Dengan Etika Sebagai Variabel Pemoderasi (Studi Empiris pada Auditor di KAP Bandung). Jurnal Riset Keuangan Dan Akuntansi, 1(02).

Nuryani, N. N. J., Satrawan, D. P. R., Gorda, A. A. N. O. S., \& Martini, L. K. B. (2018). Influence of human capital, social capital, economic capital towards financial performance \& corporate social responsibility. International Journal of Social Sciences and Humanities, 2(2), 65-76. https://doi.org/10.29332/ijssh.v2n2.128

Palan, R. (2007). Competency management. Jakarta: PPM.

Pattiasina, V., Tammubua, M. H., Numberi, A., Patiran, A., \& Temalagi, S. (2019). Capital Intensity and tax avoidance. International Journal of Social Sciences and Humanities, 3(1), 58-71. https://doi.org/10.29332/ijssh.v3n1.250

Purnomo, M. H., \& Muntasa, A. (2010). Konsep pengolahan citra digital dan ekstraksi fitur. Yogyakarta: Graha Ilmu.

Puspasari, M. A. W. (2014). Pengaruh motivasi dan budaya organisasi terhadap komitmen organisasi dan kinerja karyawan(Doctoral dissertation, Tesis Tidak Dipublikasikan).

Puspasari, M. A. W. (2014). Pengaruh motivasi dan budaya organisasi terhadap komitmen organisasi dan kinerja karyawan(Doctoral dissertation, Tesis Tidak Dipublikasikan).

Putranto, N. A. R., Gustomo, A., \& Ghazali, A. (2015). Analysis of cross cultural management course pedagogy methods in developing students' cultural intelligence. Procedia-Social and Behavioral Sciences, 169, $354-362$.

Ramdan, Z. (2008). Pengaruh kompetensi komite audit terhadap penyisian penghapusan aktiva produktif studi empiris pada bank yang terdaftar di BEI (Doctoral dissertation, Universitas Indonesia. Fakultas Ekonomi).

Ridani, M. A. (2015). Analisis Penyerapan Anggaran Belanja Daerah di Kabupaten Bulungan (Doctoral dissertation, Universitas Gadjah Mada).

Robbins, J. (2007). Perilaku organisasi, buku 1 dan 2. Jakarta: Salemba Empat.

Robbins, S. P., \& Judge, T. A. (2008). Perilaku Organisasi Buku 1, Edisi 12. Jakarta: Salemba Empat.

Sachau, D. A. (2007). Resurrecting the motivation-hygiene theory: Herzberg and the positive psychology movement. Human resource development review, 6(4), 377-393.

Safwan, N., \& Abdullah, S. (2014). Pengaruh kompetensi dan motivasi terhadap kinerja pengelolaan keuangan daerah pada Pemerintah Daerah Kabupaten Pidie Jaya. Jurnal Akuntansi ISSN, 2302, 0164.

Santoso, D., \& Irwantoro, I. (2014). Pengaruh person-organization fit (po fit) terhadap organization citizenship behaviour (OCB) dengan kepuasan kerja dan komitmen organisasi sebagai variabel intervening (Studi pada KPPBC TMP Tanjung Emas Semarang). Neo-Bis, 8(1), 32-48.

Sardiman, A. M. (2011). Motivasi Belajar Mengajar. Jakarta: Rajawali Perss.

Siagian, S. P. (2000). Administrasi pembangunan. Jakarta: Bumi Aksara.

Spencer, L. M. (86). Spencer. SM (1993). Competence at work. Models for superior performance.

Sugiyono, M. P. P. (2007). Pendekatan Kuantitatif. Kualitatif, dan R\&D, Bandung: Alfabeta.

Sugiyono, P. Dr. 2010. Metode Penelitian Kuantitatif, Kualitatif, dan R\&D. Bandung: CV Alfabeta.

Sukmasari, H. (2011). Pengaruh Kepemimpinan, Motivasi, Insentif, Lingkungan Kerja dan Kepuasan Kerja terhadap Kinerja Pegawai Dinas Pengelolaan Keuangan dan Aset Daerah Kota Semarang. Jurnal Tesis Magister Manajemen UDINUS Semarang.

Syarifudin, A. (2014). Pengaruh Kompetensi SDM dan Peran Audit Intern terhadap Kualitas Laporan Keuangan Pemerintah Daerah dengan Variabel Intervening Sistem Pengendalian Internal Pemerintah (studi empiris pada Pemkab Kebumen). Fokus Bisnis: Media Pengkajian Manajemen dan Akuntansi, 13(2).

Tarsito, S. (2014). Metode Penelitian Kuantitatif, Kualitatif dan R\&D. Alfabeta. Bandung.

Wardhana, G. A. S., Rasmini, N. K., \& Astika, I. B. P. (2015). Pengaruh Kompetensi pada Akuntabilitas Kinerja Instansi Pemerintah dengan Komitmen Organisasi Sebagai Variabel Moderasi. E-Jurnal Ekonomi dan Bisnis Universitas Udayana, 4(09), 571-598.

Asa, M., \& Sari, M. M. R. (2019). Absorption of capital expenditure budget on regional apparatus organization in East Nusa Tenggara province. International Research Journal of Management, IT and Social Sciences, 6(5), 25-39. https://doi.org/10.21744/irjmis.v6n5.694 